\title{
Impact of Lockdown and Challenges of Covid-19 on the Indian
}

\section{Economy}

\author{
R. L. Sharma \\ Department of Economics, Government College, Shimla (H. P.) \\ Email: rlsharma2008@rediffmail.com
}

\begin{abstract}
In recent years Indian economy was passing through the recession and economic slowdown now the corona virus has impacted the economy massively through the lockdown. The nationwide lockdown called in the wake of COVID-19 pandemic had taken a serious toll on the fiscal positions of the central and state government. The corona virus is spreading quickly around the globe. India is now facing its greatest crisis since its independence. In the wake of global slowdown growth of the Indian economy, the fiscal situation in the financial year is supposed to remain subdued and challenging. Indian government took the lesson from the developed countries like USA, UK and Germany and on the basis of the experiences of China and Korea to tackle this pandemic took the path of lockdown the country to save from community spread. The World Health Organization (WHO) has already declared it as world pandemic. More than 100 years later, we are witnessing the spectacle of a virus, after Spanish flew forcing nations to shut down for weeks at a time. That is why economists across the world believe that the global economy is in for its biggest recession in nearly two decades. Due to this lockdown almost every sector of the economy has been affected. The countrywide lockdown put the Indian economy into troubled waters. We have many challenges in this corona pandemic before the economy, these are revival of economy, rebuilding of confidence among the migratory labour, employment generation and control of pandemic.
\end{abstract}

\section{KEY WORDS}

Lockdown, covid-19, pandemic, gross value added, migrant labour, workforce, non-performing asset, trickledown effect, (MPLADS), MSMEs MGNREGA, fiscal deficit, GDP, unemployment

\section{Introduction}

In recent years Indian economy was passing through the recession and economic slowdown now the corona virus has impacted the economy massively through the lockdown. The corona virus is spreading quickly around the globe. India is now facing its greatest crisis since its independence. The Prime Minister of India announced complete lockdown for 21-days and subsequently 19 days lockdown to enforce self-distancing to prevent the spread of COVID-19 and flatten its growth curve. There is no remedy of this virus except the social distancing. Many developed countries including USA, UK, Spain, France and many more countries have lost thousands of their citizens after its outbreak in China. These countries took it lightly in the beginning and it lead to community spread in these countries. These countries failed to tackle it at the initial stage through social distancing, since there is no vaccination and treatment of the pandemic except social distancing. Indian government took the lesson from these countries and on the basis of the experiences of China and Korea to tackle this pandemic took the path of lockdown the country to save from community spread. The World Health Organization (WHO) has already declared it as world pandemic. It is natural that in the process, the economy is on complete bed rest. Governments, businesses and families respond to the pandemic in unprecedented ways, massively and necessarily disrupting the economy in the process. Karl Marx once wrote that a nation which ceased to work not say for a year, but even for a few weeks, would perish. The Prime Minister sh. Narinder Modi in his national address showed his concern about this lockdown. He categorically stated that this can give big jolt to our economy, if we would not follow the strict instructions of lockdown and we may go behind 21 years back. More than 100 years later, we are witnessing the spectacle of a virus, after Spanish flew forcing nations to shut down 
for weeks at a time. That is why economists across the world believe that the global economy is in for its biggest recession in nearly two decades.

\section{Methodology to access the impact on Indian Economy}

It is only premature estimation based upon the different government reports and reports available on internet and newspapers. Estimation is based on the contribution of different sectors in GDP in previous year. Gross Value Added (GVA) (GDP + Subsidies on productsTaxes) is used for estimation. In the $\mathbf{4 0}$ days lockdown there was about 80 percent loss in the production and in subsequent 30 days the loss is about 50 percent

\section{Impact of lockdown on Indian Economy}

In this article I tried to find out the cost of this lockdown in India. On 24 March, Prime Minister announced the lockdown for 21 days, it was up to 14th April, and further on the demand of the various States due to increase in the cases of covid-19 it is further increased three times at the gap of two weeks up to 31st May 2020. Though after lockdown 2.2 some relaxation were given to start the economic activities with some restrictions in some green areas and orange areas defined under covid-19 manual. The situation is unpredictable and if it happens than the period of lockdown needs be increased and it will further increase the social and economic cost. According to an estimate of Business India through the Gross Value Added (GVA) at Basic Price 2011-12, at current prices (GVA is defined as GDP + Subsidies on products-Taxes) it is claimed as a better indicator for analytics estimates. The losses are of rupees 16.68 lakh crore for 40 days lockdown and in an another estimate by care Ratings through GDP gross domestic product method it has been estimated as Rs12.3-14.2 lakh crore. In the 40 days lockdown there will be 80 percent loss in the production and subsequent 30 days the loss in the production is estimated about 50 percent. The economy will take a hit of Rs $35,000-40,000$ crore on a daily basis, shaving off Rs 14 - 16 lakh crore cumulatively, says Care Ratings for the first 40 days. We can understand the whole picture of Indian economy with the help of the sectoral contribution of different sectors in the economy through this table.

\begin{tabular}{|l|c|c|}
\hline Sector & $\begin{array}{l}\text { GVA in } \\
\text { lakh } \\
\text { Crores }\end{array}$ & $\begin{array}{c}\text { Percentage } \\
\text { to the total }\end{array}$ \\
\hline Agriculture, forest \& fishery & $\mathbf{2 7 . 7 6}$ & 16 \\
\hline Industries & 37.08 & 29 \\
\hline Manufacturing & 28.18 & 16 \\
\hline Mining \& quarrying & 4.10 & 2.6 \\
\hline $\begin{array}{l}\text { Electricity, water, gas \& other } \\
\text { utilities }\end{array}$ & 4.08 & 2.4 \\
\hline Construction hotel, transport \\
\hline $\begin{array}{l}\text { Trade, services } \\
\text { communication \& } \\
\text { related to broadcasting }\end{array}$ & 31.51 & 8 \\
\hline
\end{tabular}

\begin{tabular}{|l|c|c|}
\hline $\begin{array}{l}\text { Financial, real estate \& } \\
\text { professional services }\end{array}$ & 36.6 & 21.5 \\
\hline Services & 107.15 & 56 \\
\hline $\begin{array}{l}\text { Public Administration, } \\
\text { defense \& other services }\end{array}$ & 25.22 & 15.5 \\
\hline Total & 171.99 & 100 \\
\hline
\end{tabular}

Source: RBI handbook for the year 2018-19

The above table reveals the sectoral distribution of Indian economy. In the present scenario there is loss of about $80 \%$ in total production assuming 20 per cent of the economy (that constitutes the essential services and farming) still functions, in first quarter of the financial year 2020-21. This can be understood with the help of the table, how the different sectors of the economy suffered in the lockdown of 21 days, subsequently extended for 19 days, these are the estimates on the basis of the previous GVA. After the two subsequent lockdown of 21 days and 19 days it was further extended twice up to 31st May, 2020 with some restrictions in green areas and orange areas defined in Covid -19 manual. In these thirty days if we calculate the loss in total production by 50 percent the economy is hit by 18000-20000 crore on a daily basis 5.4-6.0 lakh crore rupees has been siphoned off.

\begin{tabular}{|c|c|c|c|}
\hline Sector & $\begin{array}{l}\text { Disruptio } \\
\text { n severity }\end{array}$ & $\begin{array}{l}\text { Loss } \\
\text { estimated } \\
\text { in Rs. } \\
\text { lakh } \\
\text { crores for } \\
40 \text { days }\end{array}$ & $\begin{array}{l}\text { Loss estimated in } \\
\text { Rs.lakh crores for } \\
30 \text { days (taken } \\
50 \% \text { severity } \\
\text { disruption in } \\
\text { production) }\end{array}$ \\
\hline $\begin{array}{l}\text { Mining \& } \\
\text { quarrying }\end{array}$ & Complete & .59 & .20 \\
\hline Construction & Complete & 2.01 & .67 \\
\hline $\begin{array}{l}\text { Trade, hotel, } \\
\text { transport } \\
\text { communication } \\
\text { \& services } \\
\text { related to } \\
\text { broadcasting }\end{array}$ & $\begin{array}{l}\text { Near } \\
\text { complete } \\
\text { excluding } \\
\text { broad } \\
\text { casting }\end{array}$ & 4.6 & $\begin{array}{l}3.45 \text { (hotel \& } \\
\text { public } \\
\text { transportation } \\
\text { almost complete } \\
100 \% \text { severity) }\end{array}$ \\
\hline $\begin{array}{l}\text { Financial, real } \\
\text { estate \& } \\
\text { professional } \\
\text { services }\end{array}$ & $\begin{array}{l}\text { Near } \\
\text { complete } \\
\text { except } \\
\text { banking } \\
\text { and health } \\
\text { care }\end{array}$ & 5.35 & 1.51 \\
\hline Manufacturing & $\begin{array}{l}\text { Near } \\
\text { complete } \\
\text { excluding } \\
\text { medicine } \\
\text { etc. }\end{array}$ & 4.11 & 1.35 \\
\hline Total & & 16.68 & 7.18 \\
\hline
\end{tabular}

In the above table in almost 70 days lockdown period in four phases there is loss of about 23.86 lakh crore rupees to the economy. It will have great impact on the growth rate of economy which was predicted about $2 \%-3 \%$ at the time of 2 nd lockdown but now even the RBI is projecting negative growth rate in the beginning of the fourth lockdown. Still the picture is not clear the virus is spreading rapidly and we are moving towards the 
community spread it will again hamper the economic activities and the loss of the economy will aggravated.

For this period agriculture sector has not been taken into consideration because during this period of lockdown the crops are almost ready for harvest and in the midst of the lockdown crops have been harvested with certain assumptions. In the present circumstances biggest hit is the sale of vegetables and floriculture in the market. Since it is perishable product and to be sold within the specific time. Due to the lockdown there is limited mobility and most of the vegetables are to be sold in the nearby market. There is mismatch between the demand and supply and the farmers are not getting the prices for their produce, even they are not meeting the cost of production. It has also impact on the production of forthcoming crops of fruits and vegetables since there is non availability of inputs. Though, the government has announced some relaxation and benefits to the farmers, but these are not enough to bail out the sector from the present crisis. If this problem is not addressed properly there may be shortage of food grains it may raise the prices and the poverty in the country will increase. According to an estimate the poverty in the country may increase from the present level of 19.25 to $31.5 \%$ by the end of the year.

Due to this lockdown almost every sector of the economy has been affected. The countrywide lockdown put the Indian economy into troubled waters. But the biggest worry due to the Covid-19 is the scale of unemployment which is far more serious this time as millions of dailywage labourers across the country stare at an uncertain future. The lockdown has brought economic activity in India to a near-complete halt in both the organized and informal sectors of the economy. Major employment generating sectors such as construction, real estate, hospitality, tourism have cut down on their services leading to unemployment. The worst hit is the small firms and their employees.

Domestically, the impact of the corona virus pandemic could lead to slowdown in domestic demand, erosion of purchasing power due to job losses or pay cuts and trickle-down effect of demand deferral will have a longer-lasting impact on some other sectors. Most of the economic disruptions affect the demand side. People can no longer go to work and often lose their jobs and incomes as businesses shutter their operations. The pandemic also hurts almost all industries, turning the health care challenge into an economic one. People can no longer travel and go out. Supply chain disruptions idle manufacturing plants. According to rating agency the Indian economy is likely to witness a sharp contraction of 4.5 per cent (de-growth) during Q4 FY20 and is expected to recover gradually, to post a GDP growth of just 2 per cent in FY21."Some of the agencies has projected even less than $1 \%$ and negative growth rate for FY21.

\section{Challenges}

We have four challenges in this corona pandemic before the economy, these are revival of economy, rebuilding of confidence among the migratory labour, employment generation and control of pandemic. The major challenge in the economy is to revive the economic activities after the completion of slowdown. In the present scenario most of the companies has suspended their production and their manpower are forced to stop the work. Most of the workforce is migratory and due to uncertainty about their jobs they left their work places to their native places. When the economic operation will start there will be gap between the demand and supply, it would be a major challenge to bridge this gap. In the initial stage the demand for the labour will also less and it will further accentuated the problem of unemployment and it will hit the demand and the problem of the economic slowdown will also increase. There will remain uncertainty about the completion of the cycle of the virus and due to that some of the migratory labour will not turn to their respective places and it will also impact the supply side and the problem will again increase the prices. The poverty in the country will be increased from the existing level. The total tax collection of the government will also be reduced and it may impact the social spending of the government. It will be a tough time for the government to revive the economy and put it on the growth track. Since the lockdown is not the permanent solution it is only a pause in the process and to provide the time to the government to think the strategy to resolve the problem. It is the time for the preparedness by way of social distancing. It cannot be a permanent solution to fight with the corona. The other major challenge is the testing of more and more persons and to provide the adequate test kits and other medical facilities. Lockdown is only the temporary solution, and it also posing the threat on the economy as all the activities are at stand still. It will pose another challenge when the lockdown will be suspended, how the states and centre will mitigate the social distancing. This problem is not up to the lockdown of 31st May, 2020 but it will remain till the suspicion of the corona virus exists.

\section{Government's Initiative}

The government has also taken some damage controlling steps to tackle this unprecedented situation. The government announced Rs 1.70 lakh crore relief packages in the form of food grains and cash transfers for the poor and vulnerable section of the society to help them deal with the hardships caused by the lockdown. As per the announcement, 80 crore poor ration card holders will each get $5 \mathrm{~kg}$ of wheat or rice and one $\mathrm{kg}$ of preferred pulses free of cost every month for the next three months, while, 20.4 crore women having Jan Dhan bank accounts would get cash help of Rs 1,500 spread over three months. Over 8.3 crore poor women, who were handed out free cooking gas connections since 
2016, will get free LPG refills for the next three months, while poor senior citizens, widows and disabled will get an ex-gratia cash of Rs 1,000. In another initiative government also announced the reduction of $30 \%$ in the salary of Ministers and Members of parliament including the President and vice President of India. The state governments are also following the same to reduce the burden on the government exchequer. At the same time, the government has decided to suspend MPLADS and funds would be directed towards improving medical infrastructure. An MP gets Rs 5 crore every year as part of the Members of Parliament Local Area Development Scheme (MPLADS). In both reduction government will save approximately Rs 8000 crores. This fund will be diverted to consolidated fund of India and it will be utilized to strengthen the medical infrastructure to fight the covid situation. The central government has also given Rs. 15000 crores to the states to combat with the corona. It will be distributed among the states on the basis of infected rates of corona in the state to strengthen the health infrastructure. The government has also created a designated Prime Minister Relief fund to combat the covid -19. Many industrialists, trusts, temples and social organizations are contributing in this fund generously for the cause. The centre government has given some guidelines to the states to start the some basic economic activities in the countries after $20 / 4 / 2020$ with maintaining the norms of social distancing certain relaxation has been given to agriculture, mgnrega, some basic retail businesses, and construction works in rural areas. It will help to restart the economy. The RBI has also injected Rs 50000 crores to increase the liquidity through NABARD, SIDBI and NHB to give the boost in the Micro, small and medium enterprises. In another initiative the RBI has reduced the repo rate and reverse repo rate to encourage the lending at this tough time. States allowed to borrow 60 per cent more via ways and means advance facility extend increased limit until Sept 30. Bad loans or nonperforming asset (NPA) classification will now happen after 180 days instead of 90 days of payment default. The government has given the special attention to agriculture sector. Procurement of wheat and oilseeds has been started w e f 15/4/2020 and other exemptions has also been given to agriculture sector to start the activities. In the beginning of May, 2020 Atmanirbhar Bharat Abhiyan slogan of 20lakh crore covid stimulus was announced by the finance Minister to restart the economy, it is $10 \%$ of the GDP. Many announcements to revive the MSMEs have been initiated like broadening of the definition of MSMEs to boost the employment opportunities and domestic production for the self reliance. Collateral free loan of Rs 3 lakh crores for MSMEs has also been announced to enable 45 lakh units to save the jobs in these units. There will be no need of global tenders up to Rs 200 crore for government purchase from these units. Special liquidity scheme Rs 30,000 crore for investing in investment grade debt paper of NBFCs, HFCs and MFIs. Has also been announced, it will be fully guaranteed by the government of India. In this package some relief was also given to migrant laborers, for those migrants who don't have NFSA cards or state cards, $5 \mathrm{Kgs}$ of wheat or rice per person and one kg channa per family per month for next two months to be provided. This will entail Rs 3,500 crore and is likely to benefit 8 crore migrants under the scheme of One Nation One ration Card. Many minor incentives has also been announced by the government in the form of loans and credit to the different section of society like interest subvention of $2 \%$ for the next 12 months under Mudra Shishu loan up to Rs 50000, loan to street vendor of Rs 10000 working capital. These two schemes have made the provision of Rs. 2000 crore loans. Similarly, some loan schemes have also been extended to affordable housing, tribal, small \& marginal farmers. These scheme accounts the total amount of Rs $1,06,000$ crore loans. These all measures of the government are to increase credit facility to increase the liquidity in the economy to gear up the economic activities after lockdown. All these measures are not sufficient to revive the economy after lockdown of covid-19.

\section{Recommendations}

Though it is very tough time for entire world to come out from this pandemic, yet there is also no reason to despair. With the right resolve and priorities, and drawing on India's many sources of strength, it can beat this virus back and even set the stage for a much more hopeful tomorrow. The immediate priority, of course, is to suppress the spread of the pandemic through widespread testing, rigorous quarantines, and social distancing. The government is drawing on our courageous medical personnel and looking to all possible measure to combat with the present situation. We should now plan for what happens after the lockdown, if the virus is not defeated. It will be hard to lockdown the country entirely for much longer periods, so we should also be thinking of how we can restart certain activities in certain low infection regions with adequate precautions. Restarting requires better data on infection levels, as well as measures to protect workers returning to work. To tackle the present economic scenario we have to develop two pronged strategy to revive the economy. We must have short term and medium term to long term plan to tackle this unprecedented economic catastrophe. In the short run government should cut down its useless expenditure heavily on all fronts with strong will. A mare cutting of the salary of MPs will only saves 50 crores, it is just an eye wash. It should be effectively reduced 30 percent on all amenities and facilities including their TA bills and other perks given to them. The similar action must be followed by the state legislatives. All the political appointments in the loss making corporations should be banned and all the heads appointed in these corporations/boards should immediately be removed. All the exemptions given to the politicians in form of Income tax should be 
withdrawn immediately. All the leaders of political parties should come forward to put the example before the masses. In India there are more than 4100 members of legislative in different states. It will save about Rs 2000 crore annually to centre and state governments. If this condition is imposed on the political leaders, all the tax payers will be ready to bear the additional cess on covid-2019 @ 6\%. It will fetch additional income to the government up to Rs 50000 crores annually. In addition to this to pump more money in the social sector to boost the demand and to help the poor an additional cess of Rs 5/per liter on petroleum products will fetch about 75000 crores annually. These measures should be started with immediate effect. It is only the will of the government that how honestly it will be implemented to revive the economy. There is a saying that every small step leads to a big journey. We have to take these measures to put the economy on the fast track. All the resources generated through these measures should be diverted to fulfill the minimum basic needs of the masses. Some minimum basic income should be given to at least one member of the family those who have lost their source of income due to lockdown. There must be some special package for the agricultural labourer. There is no provision for agriculture labourer as in the case of other categories in informal sector, More incentives should be given to Micro, mall and medium enterprises for the labour intensive techniques to provide more employment opportunities in this sector. At this stage big fiscal stimulus is required to generate the demand, though it will increase fiscal deficit but at this stage generation of demand is much more important to save employment of a person. Tax relief should be given in some sectors to boost up the production. Interest rate should be exempted for the said lockdown period particularly in the small sector industries. In the medium term plan the government should boost up the rural infrastructure by giving more opportunities in people participation through mgnrega and other such schemes. The government spending should be increased to complete the undergoing projects. There is need to give more incentives to the export sector. There is need for digitization of Indian economy for the better transparency in the present scenario. The covid-19 has shaken up the present world economic order. In the long run it is going to be changed or will remain the same it can be analyzed only after the solution of the present pandemic and similarly the Indian economic policies for the long run time will be impacted by this. There is also need to rebuild the confidence of migratory labour, some direct cash benefit must be given to them till they don't get the work. The fiscal measures taken by the government is not enough to restart the economy and to build the confidence in the economy. It needs critical analysis since it is the matter of the vital importance.

\section{Conclusion}

Though it is premature conclusion and estimation to measure the magnitude of lockdown yet there are some visible facts which support my findings. In these almost 70 days there is loss of about Rs. 24 lakh crores. Growth rate of the economy will be very less or it may be negative for the FY 2020-21 Poverty may increase from existing level of $19.6 \%$ to $30 \%$. Unemployment may increase to $26 \%$ Prices will increase due to both demand and supply constraints. Many sectors in the economy will have to bear more cost of this pandemic even after the lockdown is over. We will have to learn to live with the virus and the normal economic activities should be performed for sustenance. The More responsibility to revive the economy is on the central government and central government should help all the states irrespective of any party's government in the state for the better strengthening of the federal structure and economic recovery of the country.

\section{References}

Arora, A., Chakraborty, P., Bhatia, M. P. S., \& Mittal, P. (2020). Role of Emotion in Excessive Use of Twitter During COVID-19 Imposed Lockdown in India. Journal of Technology in Behavioral Science. https://doi.org/10.1007/s41347-02000174-3

Bansal, R., \& Gnanadev, N. (2016). Social Audit of MG NREGAs in Himachal Pradesh: Methodologies and Challenges. Journal of Business Management and Information Systems, 3(1), 97109. https: //doi.org/10.48001/jbmis. 2016.0301008

Chakraborty, P., Mittal, P., Gupta, M. S., Yadav, S., \& Arora, A. (2020). Opinion of students on online education during the COVID-19 pandemic. Human Behavior and Emerging Technologies, 66, 37-39. https://doi.org/10.1002/hbe2.240

Mittal, P. (2019). Impact of Auto-regressive (AR) Process in Bullwhip Analysis in a Multi-location Supply Chain Network. Journal of Business Management and Information Systems, 6(1), 19-26. https://doi.org/10.48001/jbmis.2019.0601002

Saxena, A., \& Bansal, V. P. (2020). CSR and Covid-19: Redefining the practices of CSR in context of Indian Industries. Journal of Business Management and Information Systems, 7(1), 47-53. https: // doi.org/10.48001/jbmis.2020.0701005

Verma, C. P., Bansal, R., \& Mittal, P. (2020). Control of COVID-19: A Counter Factual Analysis. Administrative Development, Journal of HIPA, Shimla, 7(1), 1-24. 